\title{
Front Matter: Volume 9246
}

, "Front Matter: Volume 9246," Proc. SPIE 9246, Lidar Technologies, Techniques, and Measurements for Atmospheric Remote Sensing X, 924601 (18 November 2014); doi: 10.1117/12.2177902

SPIE. Event: SPIE Remote Sensing, 2014, Amsterdam, Netherlands 


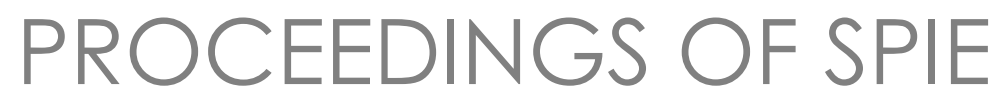

\title{
Lidar Technologies, Techniques, and Measurements for Atmospheric Remote Sensing X
}

\author{
Upendra N. Singh \\ Gelsomina Pappalardo \\ Editors
}

22 and 24 September 2014

Amsterdam, Netherlands

Sponsored by

SPIE

Cooperating Organisations

European Association of Remote Sensing Companies (Belgium)

Remote Sensing and Photogrammetry Society (United Kingdom)

European Optical Society

CENSIS—Innovation Centre for Sensor \& Imaging Systems

EUFAR-European Facility for Airborne Research

EARSeL-European Association of Remote Sensing Laboratories

TNO

ESA

Published by

SPIE

Volume 9246 
The papers included in this volume were part of the technical conference cited on the cover and title page. Papers were selected and subject to review by the editors and conference program committee. Some conference presentations may not be available for publication. The papers published in these proceedings reflect the work and thoughts of the authors and are published herein as submitted. The publisher is not responsible for the validity of the information or for any outcomes resulting from reliance thereon.

Please use the following format to cite material from this book:

Author(s), "Title of Paper," in Lidar Technologies, Techniques, and Measurements for Atmospheric Remote Sensing $X$, edited by Upendra N. Singh, Gelsomina Pappalardo, Proceedings of SPIE Vol. 9246 (SPIE, Bellingham, WA, 2014) Article CID Number.

ISSN: 0277-786X

ISBN: 9781628413090

\section{Published by}

\section{SPIE}

P.O. Box 10, Bellingham, Washington 98227-0010 USA

Telephone +1 3606763290 (Pacific Time) · Fax +1 3606471445

SPIE.org

Copyright @ 2014, Society of Photo-Optical Instrumentation Engineers.

Copying of material in this book for internal or personal use, or for the internal or personal use of specific clients, beyond the fair use provisions granted by the U.S. Copyright Law is authorized by SPIE subject to payment of copying fees. The Transactional Reporting Service base fee for this volume is $\$ 18.00$ per article (or portion thereof), which should be paid directly to the Copyright Clearance Center (CCC), 222 Rosewood Drive, Danvers, MA 01923. Payment may also be made electronically through CCC Online at copyright.com. Other copying for republication, resale, advertising or promotion, or any form of systematic or multiple reproduction of any material in this book is prohibited except with permission in writing from the publisher. The CCC fee code is 0277-786X/14/\$18.00.

Printed in the United States of America.

Publication of record for individual papers is online in the SPIE Digital Library.

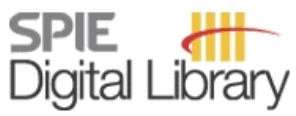

SPIEDigitalLibrary.org

Paper Numbering: Proceedings of SPIE follow an e-First publication model, with papers published first online and then in print and on CD-ROM. Papers are published as they are submitted and meet publication criteria. A unique, consistent, permanent citation identifier (CID) number is assigned to each article at the time of the first publication. Utilization of CIDs allows articles to be fully citable as soon as they are published online, and connects the same identifier to all online, print, and electronic versions of the publication. SPIE uses a six-digit CID article numbering system in which:

- The first four digits correspond to the SPIE volume number.

- The last two digits indicate publication order within the volume using a Base 36 numbering

system employing both numerals and letters. These two-number sets start with 00, 01, 02, 03, 04, 05, 06, 07, 08, 09, 0A, 0B ... 0Z, followed by 10-1Z, 20-2Z, etc.

The CID Number appears on each page of the manuscript. The complete citation is used on the first page, and an abbreviated version on subsequent pages. Numbers in the index correspond to the last two digits of the six-digit CID Number. 


\title{
Contents
}

\author{
$\vee \quad$ Authors \\ vii Conference Committee \\ ix Remote sensing at the NASA Kennedy Space Center and the Eastern Range: a \\ perspective from the ground up (Plenary Paper) [924 1-100]
}

\section{SESSION $1 \quad$ IPDA/DIAL INSTRUMENTS: CARBON DIOXIDE MEASUREMENTS}

924602 Airborne 2-micron double-pulsed integrated path differential absorption lidar for column $\mathrm{CO}_{2}$ measurement (Invited Paper) [9246-1]

924605 Satellite assisted aerosol correlation in a sequestered $\mathrm{CO}_{2}$ leakage controlled site [9246-4]

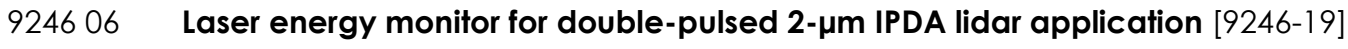

\section{SESSION 2 DIFFERENTIAL ABSORPTION LIDAR: WATER VAPOR AND OZONE MEASUREMENTS}

924608 A compact mobile ozone lidar for atmospheric ozone and aerosol profiling [9246-7]

SESSION $3 \quad$ DOPPLER LIDAR: WIND MEASUREMENTS

924609 Advanced airborne Doppler Wind Lidar signal processing for observations in complex terrain (Invited Paper) [9246-8]

9246 OA 2-micron coherent Doppler lidar instrument advancements for tropospheric wind measurement [9246-9]

\section{SESSION 4 BACKSCATTER AND RAMAN LIDAR: AEROSOLS AND CLOUDS MEASUREMENTS}

9246 OB A synopsis of CALIPSO Polar Stratospheric Cloud Observations from 2006-2014 (Invited Paper) [9246-10]

9246 OC High Spectral Resolution Lidar and MPLNET Micro Pulse Lidar aerosol optical property retrieval intercomparison during the 2012 7-SEAS field campaign at Singapore [9246-11]

9246 OD Comparison between two algorithms based on different wavelets to obtain the Planetary Boundary Layer height [9246-12]

9246 OE New lidar facility at Lindenberg Meteorological Observatory, Germany [9246-13] 
9246 OF LED mini-lidar as minimum setup [9246-14]

9246 OG Evaluation of the hygroscopic behavior of aerosols over Sao Paulo: one-day case study [9246-15]

$9246 \mathrm{OH} \quad$ Lidar measurements of tropospheric aerosol and water vapor profiles during the winter season campaigns over the metropolitan area of Sao Paulo, Brazil [9246-16]

9246 Ol MPLNET lidar data assimilation in the ECMWF MACC-II Aerosol system: evaluation of model performances at NCU lidar station [9246-17]

POSTER SESSION

9246 OJ Error propagation of exterior orientation elements study on space-borne laser altimeter ground positioning [9246-20]

9246 OK Synergy between ground-based remote sensing systems in microphysical analysis of cirrus clouds [9246-21]

9246 ON Instrumental correction of the uneven PMT aging effect on the calibration constant of a water vapor Raman lidar [9246-24]

924600 Towards an instrumental harmonization in the framework of LALINET: dataset of technical specifications [9246-25]

9246 OP An adaptive segment method for smoothing lidar signal based on noise estimation [9246-26]

9246 OT A multi-wavelength LIDAR system based on an erbium-doped fiber MOPA-system [9246-30]

9246 OU Development of a laser for differential absorption lidar measurement of atmospheric carbon dioxide [9246-31]

9246 OV Development of PM2.5 density distribution visualization system using ground-level sensor network and Mie lidar [9246-32]

9246 OW Raman lidar characterization using a reference lamp [9246-33] 


\section{Authors}

Numbers in the index correspond to the last two digits of the six-digit citation identifier (CID) article numbering system used in Proceedings of SPIE. The first four digits reflect the volume number. Base 36 numbering is employed for the last two digits and indicates the order of articles within the volume. Numbers start with 00, 01, 02, 03, 04, 05, 06, 07, 08, 09, 0A, 0B...0Z, followed by 10-1Z, 20-2Z, etc.

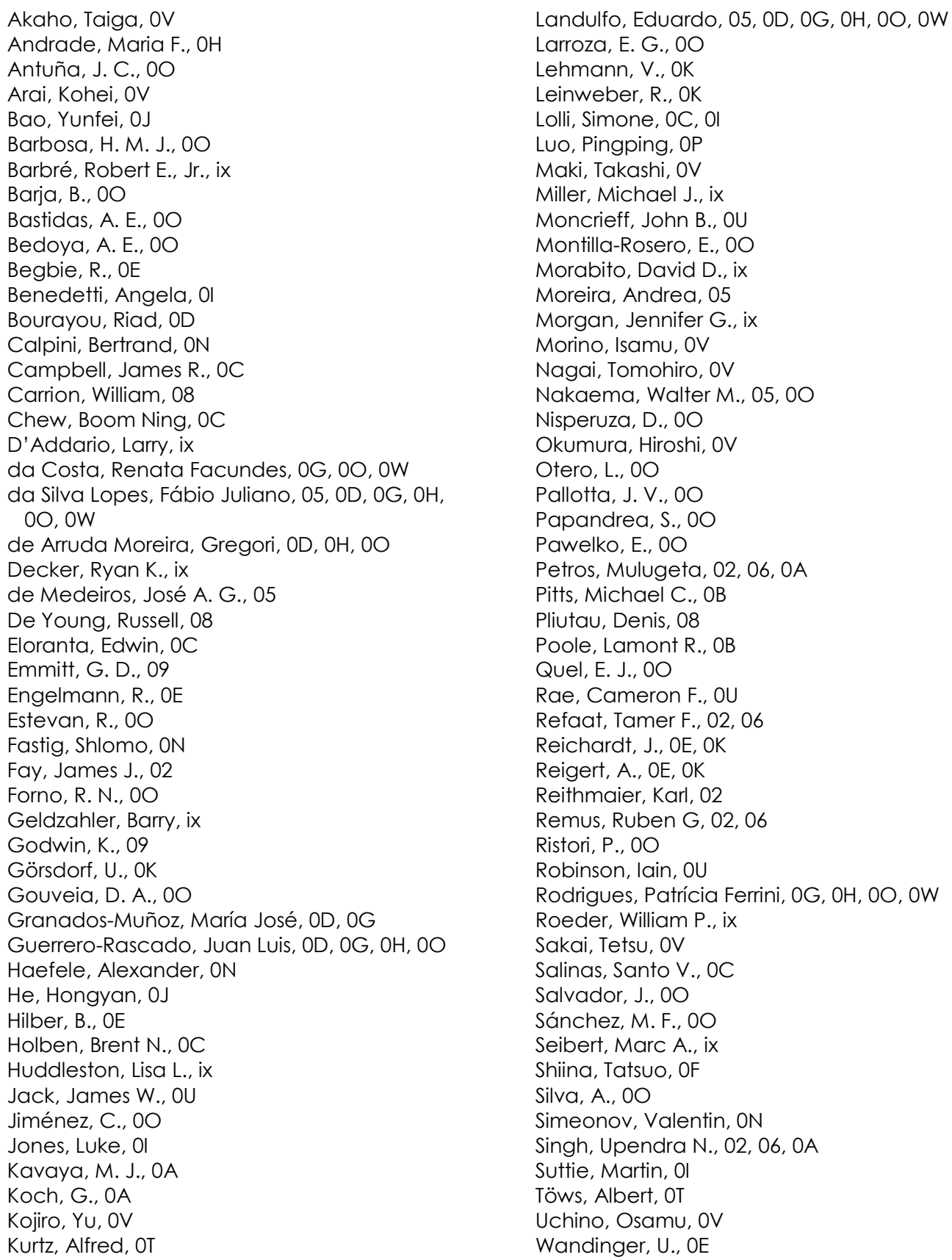


Wang, Sheng-Hsiang, $\mathrm{Ol}$

Wang, Yuzhao, OP

Welton, Ellsworth J., OC, OI

Wolf, $\mathrm{V} ., \mathrm{OE}, \mathrm{OK}$

Xing, Kun, OJ

Yamazaki, Akihiro, OV

Yokota, Tatsuya, OV

Yu, Jirong, 02, 06, 0A

Yue, Chunyu, oJ

Zhou, Nan, OJ

Proc. of SPIE Vol. $9246924601-6$

Downloaded From: https://www.spiedigitallibrary.org/conference-proceedings-of-spie on 26 Apr 2023 Terms of Use: https://www.spiedigitallibrary.org/terms-of-use 


\section{Conference Committee}

Symposium Chairs

Charles R. Bostater Jr., Florida Institute of Technology (United States)

Symposium Co-chairs

Ulrich Michel, University of Education Heidelberg (Germany)

Bart Snijders, TNO (Netherlands)

\section{Conference Chairs}

Upendra N. Singh, NASA Langley Research Center (United States)

Gelsomina Pappalardo, Istituto di Metodologie per l'Analisi

Ambientale (Italy)

Conference Programme Committee

Arnoud Apituley, Rijksinstituut voor Volksgezondheid en Milieu

(Netherlands)

Errico Armandillo, European Space Research and Technology Centre (Netherlands)

Andreas Behrendt, Universität Hohenheim (Germany)

Gerhard Ehret, Deutsches Zentrum für Luft- und Raumfahrt e.V. (Germany)

Barry M. Gross, The City College of New York (United States)

Animesh Jha, University of Leeds (United Kingdom)

Philippe L. Keckhut, LATMOS (France)

George J. Komar, NASA Headquarters (United States)

Eduardo Landulfo, Instituto de Pesquisas Energéticas e Nucleares (Brazil)

Kohei Mizutani, National Institute of Information and Communications Technology (Japan)

Doina Nicoleta Nicolae, National Institute of Research and

Development for Optoelectronics (Romania)

Alexandros D. Papayannis, National Technical University of Athens (Greece)

Vincenzo Rizi, Università degli Studi dell'Aquila (Italy)

Laurent Sauvage, Leosphere France (France)

Ulla Wandinger, Leibniz Institut für Troposphärenforschung (Germany)

Jirong Yu, NASA Langley Research Center (United States) 
Session Chairs

1 IPDA/DIAL Instruments: Carbon Dioxide Measurements

Upendra N. Singh, NASA Langley Research Center (United States)

Syed Ismail, NASA Langley Research Center (United States)

2 Differential Absorption Lidar: Water Vapor and Ozone Measurements

Jirong Yu, NASA Langley Research Center (United States)

Eduardo Landulfo, Instituto de Pesquisas Energéticas e Nucleares (Brazil)

3 Doppler Lidar: Wind Measurements

Kevin B. Strawbridge, Environment Canada (Canada)

Simone Lolli, NASA Goddard Space Flight Center (United States)

$4 \quad$ Backscatter and Raman Lidar: Aerosols and Clouds Measurements

George D. Emmitt, Simpson Weather Associates, Inc. (United States)

Mulugeta Petros, NASA Langley Research Center (United States) 